\title{
NEAR-DROWNING IN COLD FRESH WATER: CURRENT TREATMENT REGIMEN
}

\author{
A.W. Conn, J.F. Edmonds, and G.A. Barker
}

DROWNING is defined as death by suffocation under water' and annually accounts for approximately 1,300 deaths in Canada, 7,000 in U.S.A., ${ }^{2}$ and 140,000 around the world.$^{3} \mathrm{~A}$ newer term, "near-drowning", is defined as a submersion victim who arrives at an emergency facility and survives for 24 hours. ${ }^{4}$ This definition excludes those who "drowned", but ignores the degree of subsequent recovery. Contrary to some reports, ${ }^{5.6}$ most papers ${ }^{4.7 .8-10}$ and personal observation suggested that, using routine therapy, initial improvement was too often followed by progressive cerebral deterioration. Routine therapy included oxygen and artificial ventilation as indicated, rapid restoration of body temperature, circulatory support and maintenance of urine volume. In 1975, a five-year retrospective review of 30 near-drowning victims at The Hospital for Sick Children, Toronto, revealed permanent brain damage in 30 per cent ${ }^{11}$ (Table I). At that time, many reports ${ }^{12-15}$ had noted that if the drowning incident happened in very cold water. complete recovery could occur despite prolonged submersion (up to 40 minutes). ${ }^{16}$ This paper discusses those factors which affect the ultimate fate of near-drowning victims in cold fresh water and recommends rational therapeutic measures to minimize permanent brain damage.

\section{Factors Affecting Survival}

The survival and extent of recovery after a submersion accident is determined by a number of factors. These include certain physiological characteristics of the individual, the occurrence of immersion hypothermia, the submersion time, the initial resuscitation efforts and, later, the intensive care management.

It is generally accepted that, within narrow margins, there is individual variation in tolerance to, and recovery from, severe hypoxia. Of greater relevance is the age of the patient. The younger the victim the greater the possibility for complete

A.W. Conn, M.D., F.R.C.P.(C), J.F. Edmonds, M.B., F.R.C.P.(C), G.A. Barker, M.B. F.F.A.R.A.C.S., Intensive Care Unit, The Hospital for Sick Children, Toronto and the Department of Anaesthesia, University of Toronto, Toronto. recovery, ${ }^{17-19}$ partly due to the "diving reflex". ${ }^{15,20.21}$ This is a neurogenic reflex, independent of baro-receptors and chemo-receptors, which shunts blood away from non-essential organs to the heart and brain and is associated with marked bradycardia. This reflex is triggered by submersion of the face with apnoea and is most active in young children, in cold water $\left(<20^{\circ} \mathrm{C}\right)$ and is potentiated by fear. After rescue, it is usually impossible to verify the presence of this reflex, as both severe hypoxia and hypothermia can cause bradycardia. Nevertheless, even if cardiac arrest occurs after a prolonged period of bradycardia due to the driving reflex, the prognosis is much more favourable.

Immersion in very cold water $\left(5^{\circ} \mathrm{C}\right)^{22}$ has been shown to produce an incredibly rapid fall in body temperature, ${ }^{23}$ which can be accelerated by vigorous swimming. In small children the rate of temperature fall is maximal because of a relatively larger surface area and lack of insulation.9 If submerged, the swallowing of cold water in large quantities and the aspiration of ice water ( 15 per cent of cases exceed $22 \mathrm{ml} / \mathrm{kg}^{24}$ ) are additional reasons for rapid core cooling. In our series of 26 cases (1975-1977) admitted to The Hospital for Sick Children after various intervals of treatment, routine rectal temperatures ranged between $29^{\circ} \mathrm{C}$ and $39.5^{\circ} \mathrm{C}$ but were below $35.5^{\circ} \mathrm{C}$ in 46.1 per cent. In older children at approximately $35^{\circ} \mathrm{C}$ alertness and at $33^{\circ} \mathrm{C}$ consciousness are diminished, resulting in an early death from submersion and drowning* or a later death from progressive immersion hypothermia. ${ }^{25}$ In either case the victim appears irretrievably dead and resuscitation may not be attempted, which is WRONG! The rapidly lethal effect of immersion hypothermia is partly counter-balanced by producing simultaneously significant protection to the hypoxic brain. This is one of the few fringe benefits of the cold climate of central Canada. This protective effect is well documented in elective cardiovascular surgery ${ }^{20,27-30}$ where circulation can be discontinued for as long as $\mathbf{4 5}$ minutes during profound hypothermia with complete re-

*This may be defined as submersion hypothermia where immersion hypothermia occurs with asphyxia of immediate onset. 
TABLE I

Results (All Cases)

\begin{tabular}{lccc}
\hline \hline & Number & Deaths & CNS damage \\
\hline $\begin{array}{l}\text { 1970-1974 } \\
\text { (routine) }\end{array}$ & 30 & $1(3.3 \%)$ & $9(30.0 \%)$ \\
$\begin{array}{l}1975-1976 \\
\text { (Hyper R - 3 cases) }\end{array}$ & 11 & 0 & $2(18.1 \%)$ \\
$\begin{array}{l}1977 \\
\text { (Hyper R }-7 \text { cases) }\end{array}$ & 15 & $4(26.6 \%)$ & $1(6.6 \%)^{*}$ \\
Totals (1970-1977) & 56 & $5(9 \%)$ & $12(21 \%$ \\
\hline
\end{tabular}

*Admitted five days post-drowning.

covery. Since drowning is not elective (!) cooling lags behind hypoxic effects but has still proven to be protective ${ }^{13-16}$ and should be continued after rescue. In warm-water drowning with cardiac arrest, immediate induction of hypothermia has been recommended ${ }^{9,22.31,32}$ and may play a similar but less successful role.

The duration of submersion is very difficult to determine after the event, because of the emotional excitement existing at the time. Estimations in our 26 cases $(1975-1977)$ showed $<5$ minutes, 8 cases; $5-10$ minutes, 7 cases; $>10$ minutes, 6 cases; and unknown, 5 cases. It is generally accepted that 4 to 5 minutes under water at normothermia represents a maximum time before irreversible neurological damage occurs. This time-period needs re-examination in view of treatment outlined later. However, there is little doubt that full recovery is unlikely after prolonged submersions ( $>30$ minutes) even in very cold water.

The need for immediate resuscitation in all cases and regardless of circumstances cannot be over-emphasized. Mouth-to-mouth breathing and closed chest massage should be instituted in the water, if possible, and maintained as long as necessary or until cerebral death supercedes. The heart of a normothermic child, if untreated, can be restarted as long as 45 minutes after submersion, but survival with an intact brain is most unlikely. If the resuscitation time of a hypoxic normothermic heart exceeds 15 to 20 minutes, chances of complete cerebral recovery also diminish. Even a few minutes delay in commencing treatment may be critical as far as recovery of the brain is concerned. In the presence of severe immersion or accidental hypothermia, time limits should be ignored until core temperature reaches $30^{\circ} \mathrm{C}^{33,34}$

In 1975 a more aggressive approach was introduced in the intensive care management of neardrowning. This was based on the good results obtained by Dr. Mathew Spence of Auckland, N.Z., in adults with severe head injuries, ${ }^{35}$ using hypothermia and hyperventilation, among other measures, for as long as two to three weeks. It was considered that victims of near-drowning in cold fresh water might have less severe brain injury and that, using a similar approach, our results might improve. The prime aim of therapy became "cerebral salvage". At intervals during the next three years, all known measures for this purpose were gradually introduced and took absolute priority over any other therapeutic considerations. The twin goals of therapy became the preservation of any surviving cerebral cells which might be temporarily non-functioning. and the prevention of post-asphyxial brain swelling and subsequent rise in intracranial pressure. Following three years of trial and error, the following measures can be recommended as providing optimal management in near-drowning victims.

\section{METHOD OF TREATMENT}

Time is short,

The odds are great,

The margins small,

The stakes infinite...

$$
\begin{aligned}
& \text { Winston Churchill } \\
& \text { (paraphrased) } \\
& \text { "Their Finest Hour" }
\end{aligned}
$$

Following rescue, resuscitation, and stabilization of the circulation, certain clinical features appear which may affect brain recovery. These include evidence of hyperhydration and evidence of marked brain damage such as hypen'entilation, hyperpyrexia, hyper-excitability and hyper-rigidity. For discussion purposes and ease of memory, the acronym H.Y.P.E.R. will be used.

\section{Hyperhydration (H)}

During the drowning process, unknown quan- 
tities of fresh water may be both ingested and aspirated. After prolonged submersion, resuscitation requires large volumes of intravenous fluids and sodium bicarbonate as well as other volume expanders. Later, when the circulation becomes stable, there is both a relative and absolute overhydration in the presence of damaged capillaries. Fluid leaks into the tissues, particularly into the lung and the brain. This state is analogous to that of the child after prolonged cardiac by-pass surgery, who in the immediate post-operative period has no clinical (except weight gain) or haemodynamic evidence (CVP, LA or CWP all normal) of excessive third space fluid but who will later have a diuresis of several litres without hypovolaemia!

In the lung this process can easily be recognized by falling oxygen tensions, with a "wet" lung on chest X-ray and it is treated with intermittent positive pressure ventilation (I.P.P.V.) using increasing levels of both positive end-expiratory pressure (P.E.E.P.) and inspired oxygen concentrations. The use of I.P.P.V. and P.E.E.P. are well recognized causes of increased production of anti-diuretic hormone and fluid retention.

In the brain, this process of capillary leak and rising intracranial pressure is not recognizable in early stages without the use of a Richmond subarachnoid screw or intra-ventricular drain! When it is recognized clinically the process may be 100 advanced for emergency therapy.

In our experience this potential problem is best managed by prevention. Initial treatment consists of the immediate administration of furosemide $1.0 \mathrm{mg} / \mathrm{kg}$ intravenously, repeated until adequate diuresis occurs. Later, fluid restriction to half-normal maintenance is instituted and continued until the presence of clinical or laboratory evidence of dehydration is obtained.

\section{Hyperventilation (Y)}

An estimated 10 per cent of submersion victims show "dry" drowning. ${ }^{36}$ The remainder aspirate varying quantities of water. Fresh-water aspiration is less deleterious to the lung than salt water, but damage always results, especially when food or foreign material is present. Lung compliance falls and respiration increases. The unconscious patient with brain damage also increases his respiratory rate to as high as $60-80 /$ minute, producing severe respiratory alkalosis. This stimulation arises from an acidic cerebral spinal fluid secondary to brain damage and adds to the direct pulmonary change. This process causes greatly increased work of breathing, increased oxygen consumption, increased pulmonary shunting with hypoxaemia and hypocapnia. Blood oxygen tensions on arrival in emergency departments vary greatly, but in a high proportion of cases (77 per cent) ${ }^{10}$ are low. ${ }^{12}$

In all such cases, prophylactic nasotracheal intubation is done to prevent even minor airway obstruction, which can be so disastrous to the post-hypoxic brain. Intubation permits I.P.P.V. with P.E.E.P. and adequate suctioning to be performed. The presence of a small air leak around the tube prevents post-extubation complications.

After global ischaemia, cerebral shunts or steals from stages of autoregulation cannot be determined. Therefore, the $\mathrm{Pa}_{\mathrm{CO}}$ is arbitrarily maintained at $4 \mathrm{kPa}(30 \mathrm{~mm} \mathrm{Hg})$. This is a compromise between excessive hypocapnia with possible cerebral vasoconstriction, and normoor hyper-capnia with excessive cerebral blood flow and raised intracranial pressure. Nevertheless, if an abrupt rise of intracranial pressure occurs, hyperventilation can be increased temporarily to deal with such emergencies.

The inspired oxygen concentration is maintained at 70 per cent or more and the risk of pulmonary toxicity is accepted. A high blood oxygen level theoretically favours oxygen diffusion through the oedematous peri-capillary areas of the brain. P.E.E.P. of $0.67-1.33 \mathrm{kPa}(5-10 \mathrm{~mm}$ $\mathrm{Hg}^{37}$ provides adequate oxygenation in most cases and avoids a possible rise of cerebral venous pressure (I.C.P.) and pulmonary microatelectasis.

\section{Hyperpyrexia (P)}

Fever commonly follows near-drowning 2.38 and has exceptionally deleterious effects on a damaged brain. It is believed, on circumstantial evidence, that damaged neurones which are not functioning may recover if oxygen requirements are reduced and increases in intracranial pressure are prevented. ${ }^{39,40}$ It is argued that if prophylactic elective hypothermia gives the brain excellent protection, and simultaneous immersion hypothermia gives good protection, then delayed therapeutic hypothermia may give some protection if instituted immediately. Therefore, immersion hypothermia should be maintained and if the unconscious patient is normothermic, then moderate hypothermia should be induced within two hours of injury. ${ }^{41}$ Hypothermia reduces the body's total oxygen requirements in a linear manner ${ }^{29}$ so that at $30^{\circ} \mathrm{C}$ both total body and cerebral oxygen requirements are reduced by half. Cerebral blood flow also falls and intracra- 
nial pressure falls 5.5 per cent $/ 1^{\circ} \mathrm{C}$ at $25^{\circ} \mathrm{C} .42$ Cerebral metabolism is only 30 per cent of normal at $25^{\circ} \mathrm{C}^{43}$ but there is a high incidence of spontaneous ventricular fibrillation.

Using cooling blankets and relaxants, body temperature should be rapidly reduced and maintained at $30 \pm 1^{\circ} \mathrm{C}$. This level achieves a satisfactory reduction in both cerebral oxygen requirements and intracranial pressure and is above the upper level for spontaneous ventricular fibrillation (approximately $28^{\circ} \mathrm{C}$ ).

Chlorpromazine $5-25 \mathrm{mg} \mathrm{q} 8 \mathrm{~h}$ is given intramuscularly to promote vasodilation, to prevent shivering and to potentiate other drugs.

\section{Hyper-excilability (E)}

Acute brain damage is frequently associated with grunting, athetoid movements and "straining" '. Such movements are prone to raise intracranial pressure. Less commonly, grand mal seizures occur which are deleterious both directly and indirectly. Barbiturates have been used recently in large doses to protect the brain. ${ }^{44,45,46}$ Pentobarbitone has a shorter duration of action than phenobarbitone and is not dependent on renal excretion. The summation of beneficial metabolic effects of barbiturate treatment when combined with hypothermia has been reported ${ }^{46}$ and refuted. ${ }^{47}$ Steroids are ineffective in the treatment of the pulmonary lesion in fresh-water drowning $^{48}$ but are known to prevent a rise in intracranial pressure $e^{46.49}$ and improve cerebral compliance.

Currently recommended doses are: pentobarbitone $2-3 \mathrm{mg} / \mathrm{kg} / \mathrm{q} / \mathrm{h}$ intravenously (maintain blood level between 2.5 and $4.0 \mathrm{mg} / 100 \mathrm{ml}$ ), ${ }^{50}$ Methylprednisoline $1.0 \mathrm{mg} / \mathrm{kg} / \mathrm{day}$ in 4 doses $^{41}$ (start treatment within 6 hours).

\section{Hyper-rigidity (R)}

Decerebrate rigidity is an obvious cause of severe rise in intracranial pressure. More subtle causes include simple nursing procedures such as lowering the head, or tracheal suctioning through the nasotracheal tube which may precipitate a rise in intracranial pressure of 30 minutes' duration! For these reasons, as well as the need to control ventilation, complete muscle paralysis is maintained continuously. For this purpose we use d-tubocurare $0.5-1.0 \mathrm{mg} / \mathrm{kg} / \mathrm{hr}$ intravenously or p.r.n. to prevent movement or pancuronium $0.1 \mathrm{mg} / \mathrm{kg} / \mathrm{hr}$ intravenously or p.r.n. to prevent movement.

On arrival at hospital all submersion victims who are conscious and alert should be admitted for 24 hours observation ${ }^{2,9.12,41}$ to detect subtle cerebral or pulmonary changes at an early stage and to prevent delayed death. 22.38.49.51 "Coning" is unpredictable and can occur with little warning and dire results. All immersion victims who are unconscious should have the full therapy started and should be transferred to the intensive care unit immediately. Fortunately for the patient reaching tertiary care facilities, there is usually a one to two hour lag before intracranial pressure rises precipitously. After eight hours delay in treatment, little benefit can be expected.

Full treatment should be continued for 48 hours before discontinuing relaxants and barbiturate therapy. Fortunately recovery is slow and if the intracranial pressure rises then therapy must be re-instituted for another 48 hours, as cerebral compliance must be low. One of our cases in 1977 was fully awake after 48 hours of full treatment only to relapse and die a rapid neurological death. Transient small rises in intracranial pressure can be treated with mannitol $1.0 \mathrm{gm} / \mathrm{kg}$ intravenously or increased ventilation. Surgical decompression has not been necessary but has been very successful in our treatment of Reye's Syndrome. The only indication for discontinuing treatment at any time is the presence of "cerebral death" (determined by flat electroencephalogram, "A" waves, difficulty in maintaining temperature and circulation, etc.).

Full-time nursing and physician coverage is essential. Monitoring requirements are obviously extensive but available in any Intensive Care Unit and will not be itemized. We have only lim. ited experience so far with a Richmond Screw in near-drowning cases but have found its use in similar situations invaluable. A subarachnoid screw (Bolt?) or an intraventricular drain for continuous monitoring of intracranial pressure is mandatory. We have had no experience with continuous E.E.G monitoring, which may be helpful.

\section{Discussion}

This is a small series of cases containing a large number of uncontrollable variables. After the 1970-1974 period we began to introduce more aggressive measures in stages and therapy is still evolving. In 1978, "HYPER" therapy was instituted on all unconscious drowned patients regardless of possible benefit. It is believed that even in hopeless cases, a 24-hour period of observation and therapy allows both the physicians and parents to make adjustments and judgements. In "lighter" levels of consciousness, full 
TABLE II

RESULTS (HYPER R)

\begin{tabular}{lclc}
\hline & Number & Deaths & CNS damage \\
\hline 1975 & 2 & 0 & 0 \\
1976 & 1 & 0 & 1 \\
1977 & 7 & $4^{*}$ & 0 \\
ToTaL (1975-1977) & 10 & $4(40 \%)$ & $1(10 \%)$ \\
\hline
\end{tabular}

*One case, recovered completely and relapsed; One case, treated after 4 hours; One case, treated after $3 \frac{1}{2}$ hours; One case, $>30$ minutes submerges.

therapy is also indicated because spontaneous complete recovery is quite unpredictable. This may be considered therapeutic "overkill" but a decision to forgo full treatment without reliable guidelines can lead to tragedy. There were no major complications of "HYPER" therapy except for one child who made a complete recovery after 48 hours' treatment only to relapse abruptly and die a brain death. Other complications such as pulmonary oedema, haemolysis, anuria and pneumonia were infrequent but will not be discussed as the brain remains the weakest link in recovery from asphyxia! The risk that this aggressive treatment would leave many more patients in a permanent vegetative state appears to be groundless (Table II). All submersion victims should be admitted 24 hours for study and observation to prevent "secondary" drowning.

\section{Conclusions}

Within obvious but uncertain limits, the therapeutic regimen recommended for neardrowning in "cold" fresh-water victims should improve their prognosis. Despite limited cases, a large number of uncontrollable variables, our results would appear to support this concept. Final proof awaits a larger series and the results of animal experiments. Application of these "HYPER" principles can be justified but is less successful in brain injury from other causes, e.g., warm-water drowning, post-cardiac arrest, Reye's Syndrome, etc. Meanwhile, future neardrowning victims must be treated as they arrive, and the principles of cerebral salvage must receive prime consideration.

\section{SUMMARY}

Near-drowning victims are admitted to tertiary care facilities within a few hours of submersion. Following initial improvements, many patients undergo progressive cerebral deterioration. A retrospective study (1970-1974) of 30 patients at
The Hospital for Sick Children, Toronto, revealed a mortality of 3.3 per cent and permanent brain damage in 30 per cent. At the same time, excellent results were reported, using an aggressive treatment of closed-head injuries, following cold-water water drownings and in the use of profound hypothermia in cardiovascular surgery. In 1975 some specific therapeutic measures were instituted for near-drowning victims and have subsequently been revised and extended.

The goal of treatment is to prevent a significant rise in intracranial pressure while maintaining optimal conditions for cerebral recovery. Therefore therapy is instituted immediately and continued as long as necessary. Treatment is often facilitated by the presence of immersion hypothermia. This regimen includes: $(a)$ severe restriction of hydration; (b) controlled ventilation to obtain high oxygen blood levels and mild hypocarbia $\left(\mathrm{Pa}_{\mathrm{CO}_{2}} 4 \mathrm{kPa}[30 \mathrm{~mm} \mathrm{Hg}]\right.$ ); (c) moderate hypothermia $\left(30^{\circ} \mathrm{C}\right)$; $(d)$ control of hyperexcitability by large doses of barbiturate and steriods and $(e)$ control of hyper-rigidity by relaxants. Monitoring of all body systems is necessary and the continuous monitoring of intracranial pressure is mandatory.

The results during evolution of treatment (1975-1977) in 26 cases showed 15.4 per cent mortality and brain damage in 7.7 per cent. In this limited series, with numerous variables, these results suggest that this therapeutic trial should be continued.

In conclusion, statistical proof to justify these measures is not yet available clinically or experimentally. However, the magnitude of the problem, when associated with the minimal morbidity of treatment, justifies continuation of the program and possible extension to other types of brain injury.

\section{RÉSUMÉ}

Les survivants de noyade sont hospitalisés dans des unités de soins tertiaires quelques 
heures après l'accident. Après une amélioration initiale, beaucoup de ces patients manifestent une détérioration cérébrale progressive. Une analyse rétrospective portant sur trente patients hospitalisés à l'Hôpital Sick Children de Toronto entre 1970 et 1974, a mis en évidence une mortalité de 3.3 pour cent et des dommages cérébraux permanents chez 30 pour cent des patients. Au cours de la méme période, l'on rapportait d'excellents résultats avec l'emploi d'une thérapie agressive dans les cas de traumatismes crâniens fermés, chez les survivants de noyade en eau froide et en chirurgie cardiovasculaire sous hypothermie profonde. En 1975, un protocole de traitement était établi pour les survivants de noyade, protocole qui a depuis été révisé et modifié au besoin.

L'objectif du traitement est de prévenir une augmentation de la pression intra-crânienne tout en maintenant des conditions optimales pour la récupération cérébrale. Ceci implique: $(a)$ une hydratation réduite au minimum; $(b)$ une ventilation contrôlée pour obtenir une $\mathrm{Po}_{2}$ élevée avec hypercapnée modérée $\left(\mathrm{Pa}_{\mathrm{CO}_{2}} 4 \mathrm{kPa}(30 \mathrm{~mm} \mathrm{Hg})\right)$; (c) une hypothermie modérée $\left(30^{\circ} \mathrm{C}\right) ;(d)$ le contrôle de l'hyper-excitabilité cérébrale au moyen de doses élevées de barbituriques et de stéroïdes; (e) et enfin le contrôle des états d'hyperrigidité au moyen de curarisants. Une monitoring efficace de toutes les grandes fonctions, $y$ compris le monitoring constant de la pression intracrânienne est essentiel.

Nous avons observé une incidence de 7.7 pour cent de dommages cérébraux permanents a vec une mortalité à 15.4 pour cent chez 26 patients ainsi traités entre 1975 et 1977. Même si notre série est petite et présente de nombreuses variables, de tels résultats justifient, croyonsnous, la poursuite de l'évaluation de cette approache thérapeutique.

En conclusion, mème si la preuve statistique de la validité clinique et expérimentale de ces mesures n'est pas encore disponible, le maintien d'un tel protocole et peut-être son application à d'autres cas de traumatismes cérébraux, nous semblent justifiés, surtout si l'on considère la gravité de la pathologie en cause et la morbidité minime liée au traitement lui-même.

\section{ACKNOWLEDGEMENTS}

The authors wish to thank Dr. George Montes and the other Residents, Nurses and Technicians of the Intensive Care Unit who have worked so hard in the interests of these patients.

\section{REFERENCES}

1. The Shorter Oxford English Dictionary, 3rd ed. 1964, Oxford University Press, Amen House, London E.C. 4.

2. Giammona, S.T. Drowning: pathophysiology and management. Current Problems in Paediatrics, 1(7): $1-33(1971)$.

3. Clarke, E.B. \& Niggemann, E.H. Near drowning. Heart and Lung 4(6): 946-955 (1975).

4. Schuman, S.H., Rowe, J.R., Glazier, H.M., \& REDDING, J.S. The iceberg phenomenon of near drowning. Society of Crit. Care Med. 4(2): 127 (1976).

5. Eriksson, H.F., Gerdman, P., \& Thorson, J. Sequelae of accidental near-drowning in childhood. Scand. J. Soc. Med. I: 3 (1971).

6. Pearn, J. Neurological and pscyhometric studies in children surviving fresh-water immersion accidents. Lancet, January 1 (1977).

7. SegarRa, F. \& Redding, R.A. Modern concepts about drowning. C.M.A. 110:1057-1062 (1974).

8. Plueckhahn, V.D. Death by Drowning? Geelong 1959-1974. Med. Journal of Australia 2: 904-906 (1975).

9. Craig, A.B., Cranes, S.A., Kwudoson, R.D., \& MODELL, J.H. Drowning's deadly toll - catn more be saved? The Physician and Sports Medicine Magazine, pp. 28-41 (August 1977).

10. Petersen, B. Morbidity of childhood neardrowning. Pediatrics 59: 364-370 (1977).

11. CONN, A.W. The role of hypothermia in neardrowning. Proceedings of "Cold Water Symposium ', Royal Life Saving Society of Canada, pp. 33-35 (May 8, 1976).

12. MODELL, J.H. The pathophysiology and treatment of drowning. Chas. C. Thomas, Springfield, Illinois (197i).

13. Dominguez de Villota, E., Barat, G., Peral, P., Juffie, A., Fernandez, J.M., \& Avello, F. Recovery from profound hypothermia with cardiac arrest after immersion. Brit. Med. J. 4 : 394 (1973).

14. KVitTingen, T.D. \& NaEss, A. Recovery from drowning in fresh water. Brit. Med. J. $1: 1315$ (1963).

15. HUNT, P.K. Effect and treatment of diving reflex, C.M.A. 111: 1330-1331 (1974).

16. Sietke, H., RøD, T., BReivik, H., \& LiNd, B. Survival after 40 minutes submersion without cerebral sequelae. Lancet $I, 1275-1277$ (1975).

17. PEARN, J., Nixon, J., \& WILKEY, I. Freshwater drowning and near-drowning accidents involving children: a 5-year total population study. Med. J. of Australia 2: 942-946 (1976).

18. Strono, M.J. \& Keats, A.S. Induced hypothermia following cerebral anoxia. Anesthesiology 28 : 920-923 (1967).

19. ORLOWSK1, J.P. Prognostic factors in drowning and the post-submersion syndrome. Crit. Care Med. 6(2): 94 (1978).

20. Editorial: Drowning and the diving reflex. C.M.A.J. 108: 1209 (1973).

21. Natural Life Preservers. Time Magazine (Medicine), pp. 45-46 (Aug, 22, 1977),

22. Golden, F. St C. \& Rivers, J.F. Thoughts on immediate care: the immersion incident. Anaesthesia $30: 364-373$ (1975). 
23. Keatinge, W. The concept of hypothermia. Proceedings of "Cold Water Symposium", The Royal Life Saving Society Canada, Toronto (May 8 , 1976).

24. Model, J.H. \& DAvid, J.H. Electrolyte changes in human drowning victims. Anesthesiology 30(4): 414-420 (1969).

25. KeAting, W.R. Survival in cold water, Blackwell Scientific Publications, p. 5 (1969).

26. CONn, A.W. \& MUSTARD, W.T. Hypothermia for cardiac surgery in paediatric surgery. Chicago Year Book Publishers (1969).

27. Wagner, h.R. \& Subramanian, S. Deep hypothermiat in infant cardiac surgery. Paediatrics 6I(3): 479-483 (1978).

28. HaKa-IKSE, K., BLACKWOOd, M.J.A., \& STEWARD, D.J. Psychomotor development of infants and children after profound hypothermia during surgery for congenital heart disease. Develop. Med. Child. Neurol. 20: 62-70 (1978).

29. VIRTUE, R.W. Hypothermic anaesthesia. Charles C. Thomas, Springfield, Ill. (1955).

30. Steward, D.J., Sloan, I, A., \& Johnston, A.E. Anaesthetic management of infants undergoing profound hypothermia for surgical correction of congenital heart defects. C.A.S.J. 21: 15-22 (1974).

31. Redding, J.S.. Yakaitis, R.W., \& HerschelKING, C. Problems in the management of drowning victims. Maryland State Medical Journal 19: 58 (1970).

32. Ohlsson, K. \& Beckman, M. Drowning-reflections based on two cases. Acta. Chir. Scand. 128 $327-339$ (1964)

33. Fallis, J.C. Accidental hypothermia (personal communication).

34. Bristow, G., Smith, R., Lee, J., Auty, A., \& TWEED, W.A. Resuscitation from cardiopulmonary arrest during accidental hypothermia due to exhaustion and exposure. C.M.A.J. 117: 247-249 (1977).

35. Mathew Spence, Auckland, N.Z. (personal communication).

36. Modell, Jerome. Pulmonary insults, drowning aspiration pneumonitis. A.S.A. Refresher Course Lecture \# 108: 1-6 (October 12-16, 1974).
37. Modell, J.H., Calderwood, H.W., Ruiz, B.C.. DOWNS, J.B., \& Chapman, R., JR. Effects of ventilatory patterns on arterial oxygenation after near-drowning in sea-water. Anesthesiology 40(4): 376-384 (1974)

38. SegarRa, F. \& Redding, R.A. Modern concepts about drowning, C.M.A. /10: 1057-1062 (1974).

39 Fisk, et al. Influence of duration of circulatory arrest at $20^{\circ} \mathrm{C}$ on cerebral changes. Anaesthesia and Intensive Care 4: 126 (1976).

40. Black, P.R., Van Devawter, S., \& Cohn, L.H. Effects of hypothermia on systemic and organ system metabolism and function, J. or Surg. Research. 20:49-63 (1976).

41. BATZDORF, $U$. The Management of cerebral edema in paediatric practice. Paediatrics 58(1): 78-87 (1976).

42. RosomofF, H.L. \& GileerT, R. Brain volume and C.S.F. pressure during hypothermia. Am. J. Physiology 183: 19 (1957).

43. Mowat, D. Hypothermia, in clinical surgery. Eds. Rob, C. \& Smith, R. Butterworth and Co. (Publishers) Ltd., pp. 146-168 (1964).

44. SMITH, A.L. Barbiturate protection in cerebral hypoxia. Anesthesiology 47: 285-293 (1977).

45. Marsh, M.L., Marshall, L.F., \& Shapiro. H.M. Neurosurgical intensive care. Anesthesiology 47:149-163 (1977).

46. Shapiro, H.M. Anaesthesia, intensive care and the neurosurgical patient. A.S.A. Refresher Lecture Series (1975).

47. Hägerdal, M., Welsh, F.A., Keykhah, M., \& HARP, J.R. The protective effects of a combination of hypothermia and barbiturates in cerebral hypoxia. Crit. Care Med. 6(2): 110-111 (1978).

48. Calderwood, H.W., Modell, J.H., \& Ruiz, B.C. The ineffectiveness of steroid therapy for treatment of fresh-water near-drowning. Anesthe siology 43(6): 642-650(1975).

49. Fishman, R.A. Brain edema. N.E.J.M. 293 : 706-711 (1975)

50. Marshall, L.F., Shapiro, H.M., Rauscher, R., \& Kaufman, N.M. Pentobarbilal therapy for intracranial hypertension in metabolic coma. Crit. Care Med. 6(1): 1-5 (1975).

51. BARR, A.M. \& TAYLOR, M. A case of drowning. Anaesthesia 3/(5): 651-657 (1976). 